原著

坐位での頭振りを施行させた外側半規管型

（クプラ結石症）頭位めまい症

堀池 修・池田 卓生・橋本 誠

山崎 愛語・山下 裕司

\title{
Horizontal Canal Positional Vertigo of Cupulolithiasis Evoked by Head-Shaking while Sitting
}

\author{
Osamu Horiike, Takuo Ikeda, Makoto Hashimoto, \\ Aigo Yamasaki, Hiroshi Yamashita \\ Department of Otolaryngology, Yamaguchi University School of Medicine
}

\begin{abstract}
Peripheral positional vertigo is the most common type of vertigo due to peripheral vestibular lesion. Recently, peripheral positional vertigo is classified according to different lesions of originating in the canal. The posterior canal positional vertigo is so called benign paroxysmal positional vertigo. In horizontal canal positional vertigo of cupulolithiasis, the direction-changing horizontal ageotropic nystagmus is caused by cupulolithiasis, these patients cannot be diagnosed early. In addition, the attack period tends to persist for a few months. Therefore, we developed a new method of a headshaking in anteflexio while sitting. In this study, two patients with horizontal canal positional vertigo of cupulolithiasis performed anteflexio head-shaking while sitting and were examined using an infrared CCD camera. By anteflexio head-shaking while sitting, we were able to easily transfer horizontal canal positional vertigo of cupulolithiasis to canalolithiasis. Furthermore, positional nystagmus disappeared by the modified Lempert method.
\end{abstract}

Key words: peripheral positional vertigo, horizontal canal positional vertigo of cupulolithiasis, canalolithiasis, cupulolithiasis, modified Lempert method

\section{はじめに}

近年末梢性頭位めまい症についての考え方が急 速に整理されて，回旋成分が主たる後半規管型

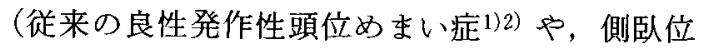
で水平成分が主たる外側半規管型等が考兄られる よらになってきた。た病態として，剝脱した耳

山口大学医学部耳鼻咽喉科学教室
石あるいはそれに関連した物質 (debris) が，半 規管内に浮遊した状態 (半規管結石症・canaloli-

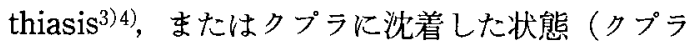
結石症 - cupulolithiasis ${ }^{5}$ ) との考方方が一般的と なってきた。半規管結石症やクプラ結石症との認 識に伴い，半規管結石症に対して浮遊耳石置換法 (Epley 法4), Lempert 法6) 等) が, クプラ結石 症に対して非特異的な理学療法（Brandt-Daroff 
法7) 等）が用いられ，半規管結石症に対する浮遊 耳石置換法に関してはその有効性も多数報告され てきている8) 13)。しかしながら，クプラ結石症 については診断に苦慮することが多く，また慣れ を期待した非特異的な治療法7)では体動による患 者負担も大さい。そこで我々は，外側半規管型 (クプラ結石症) 頭位めまい症に対して, 患者負 担が小さい坐位での頭振りにより，クプラ結石症 を半規管結石症へと比較的容易に移行させると考 えられる方法を考案した。今回我及は外側半規管 型（クプラ結石症）頭位めまい症 2 症例に本法を 施行させ, 比較的早期に半規管結石症に移行させ ることができたので, 経過を含め若干の文献的考 察を加觉報告する。

\section{症例}

症例 $1: 54$ 歳, 女性。

現病歴: 平成13年 7 月 4 日朝起床後より突然回 転性めまいが出現し, 当科外来を受診した。蝸牛 症状及びその他の神経症状はなかった。

既往歴 : 特記すべきことなし。頭部打撲等の既 往なし。めまいのエピソードなし。中耳炎の既往 なし。
家族歴：特記すべさことなし。

その他：就寝時に右側卧位になることが多い。 耳鼻咽喉一般所見：特記すべきことなし。

眼振所見：図 1 亿外来初診時に赤外線 $\mathrm{CCD}$ 力 メラで観察した仰臥位での眼振所見と，池田が報 告した眼球運動画像解析法 ${ }^{14)}$ を用いた眼振波形 を提示する（以後の眼振所見は全て同様に観察し 解析した）。仰臥位右下頭位で左向き水平性眼振, 仰臥位左下頭位で右向さ水平性眼振となる, 万向 交代性上向性眼振を認姱。仰臥位左下頭位の方 が右下頭位に比較して振幅が大きく, 自覚症状も 強かった。潜時は汪とんどなく疲労現象も認めず 持続性であった。坐位では眼振は消失した。

標準純音聴力検査：正常, DPOAE - TPOAE : 正常。

ABR：I-V波間潜時の延長なく, 正常。

平衡機能検査: 2 点交互視, 指標追跡検査, 視 運動性眼振検查では異常を認めなかった。 $20^{\circ} \mathrm{C}$ 少量注入法によるカロリックテストでは両側とも 正常反応であった。重心動摇検査では, 開眼及び 閉眼時に軽度動摇面積の増加を認めた。

その他検查 : 頭部 MRI を含め当院神経内科に
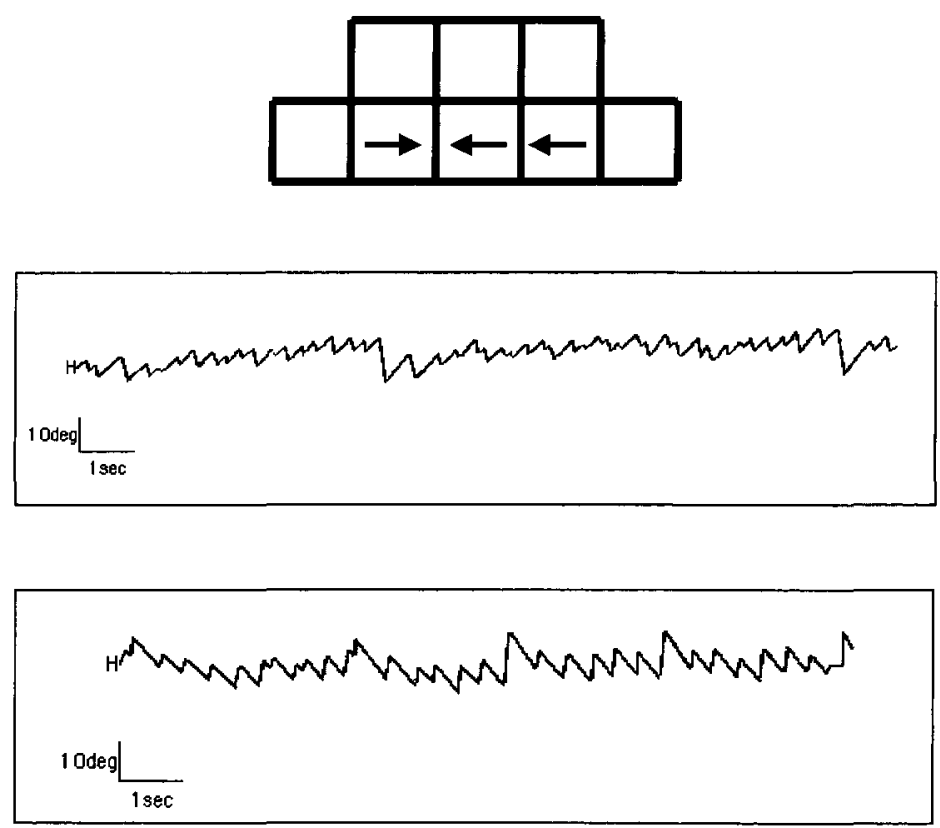

図 1 上段 : 初猃時の仰臥位での眼振所見 中段 : 仰臥位右向きの眼振解析図 下段：仰卧位左向きの眼振解析図 
执いて中枢性病変の精査を施行したが異常は指摘 されなかった。

経過：同日当科入院となった。眼振所見及び他 の諸検査から, 右外側半規管のクプラに debris が沈着した外側半規管型（クプラ結石症）頭位め まい症と診断した。そこで 1 日 3 回 30 秒程度の坐 位での頭振りを施行させた。実際の頭振りは体幹 軸を中心ではやや困難を伴らため, 頭を振る速度 や振幅はある程度は患者本人にアレンジして無理 なく施行させた。その際, 坐位で行らこと, 気分 不良等の症状があれば直ちに止めること, 等を説 明した上で施行させた（図 2 )。めまい症状は徐 徐に軽減し, 3 日目に眼振所見は, 仰臥位右下頭 位で右向き水平性眼振, 仰臥位左下頭位で左向き 水平性眼振となる方向交代性下向性眼振に変化し た (図 3 )。この眼振所見の変化から, 右側の外 側半規管型頭位めまい症が, クプラ結石症から半 規管結石症に移行した状態であると診断し, 同日 右耳を患側として Lempert 変法 ${ }^{12}$ ) (Lempert 法6) が仰臥位で健側耳向きに, 寝返りの如く90度 ずつ頭部を270度回転するのに対し, Lempert 変 法12) では更に 90 度回転を加光 1 回転し仰臥位に 戻る方法）を施行した結果, 直後より眼振は完全 に消失した。その後眼振は再発せず退院となり,
外来通院に打いて以後 6 力月間経過を観察してい るが，再燃を認めていない。

症例 $2: 54$ 歳, 男性。

現病歴: 平成 12 年 6 月 14 日突然回転性めまいが 出現し, 当初血栓性の中权疾患が疑われ, 直ちに 当院脳神経外科・神経内科紹介受診となった。頭 部の MRI, MRA 含め精査施行するも, 特に異 常を指摘されず，めまいの原因として中枢性疾患 の関与は否定的であったため, 同年 6 月 23 日当科 外来紹介受診となった。

既往歴: 右肺癌のため平成 12 年 4 月 4 日当院外 科入院の上, 4 月 18 日全身麻酔下で右肺全摘出術 施行された。このため横になった時左側を下にす ることが多かった。頭部打撲等の既往なし。めま いのエピソードなし。中耳炎の既往なし。

家族歴 : 特記すべきことなし。

耳鼻咽喉一般所見 : 特記すべきことなし。

眼振所見 : 図 4 亿外来初診時の仰臥位での眼振 所見を示す。仰臥位右下頭位で左向き水平性眼 振, 仰臥位左下頭位で右向き水平性眼振となる方 向交代性上向性眼振を認め, 仰臥位右下頭位の方 が左下頭位に比較して振幅・頻度ともに大きく, 症状も強かった。眼振はほとんど潜時を認めず疲 労現象なく持続性であった（図 4 ）。
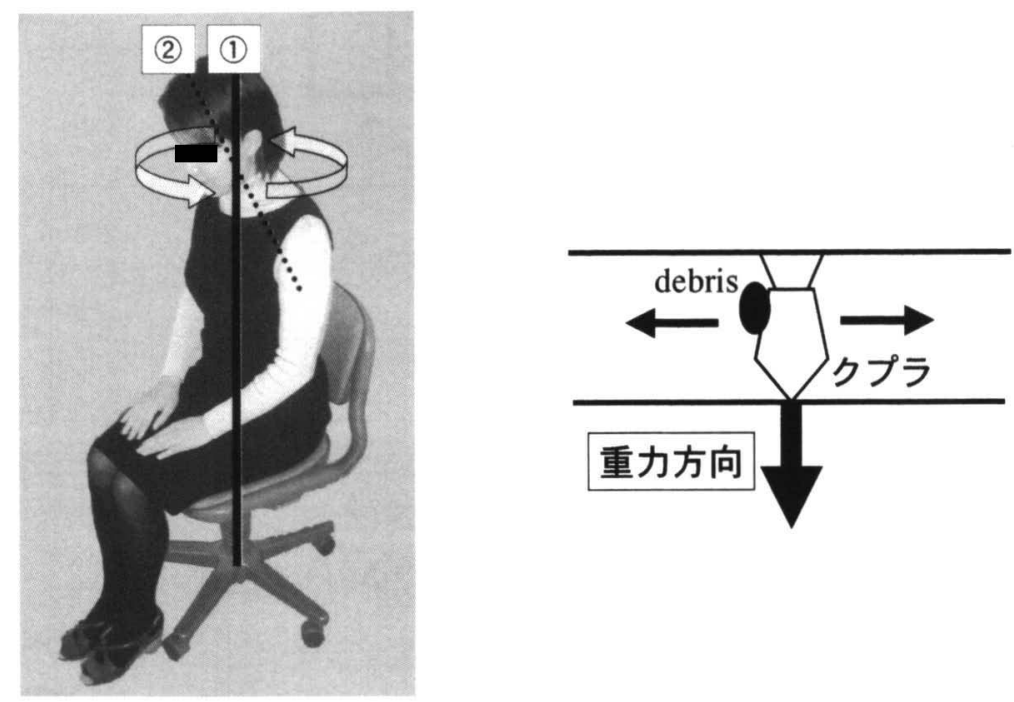

図 2 左図は頭部前屈位での頭振りを行っている状態 右図はその状態での外側半規管内のクプラと debris を考察した図 坐位頭部前屈位30度 (2) で体幹軸（11）を中心に頭振りを行ら。外側半規管がほぼ水平性になるためク プラの移動方向と重力の方向が垂直となり仰臥位での頭振りと比較して重力の影響が小さい。 

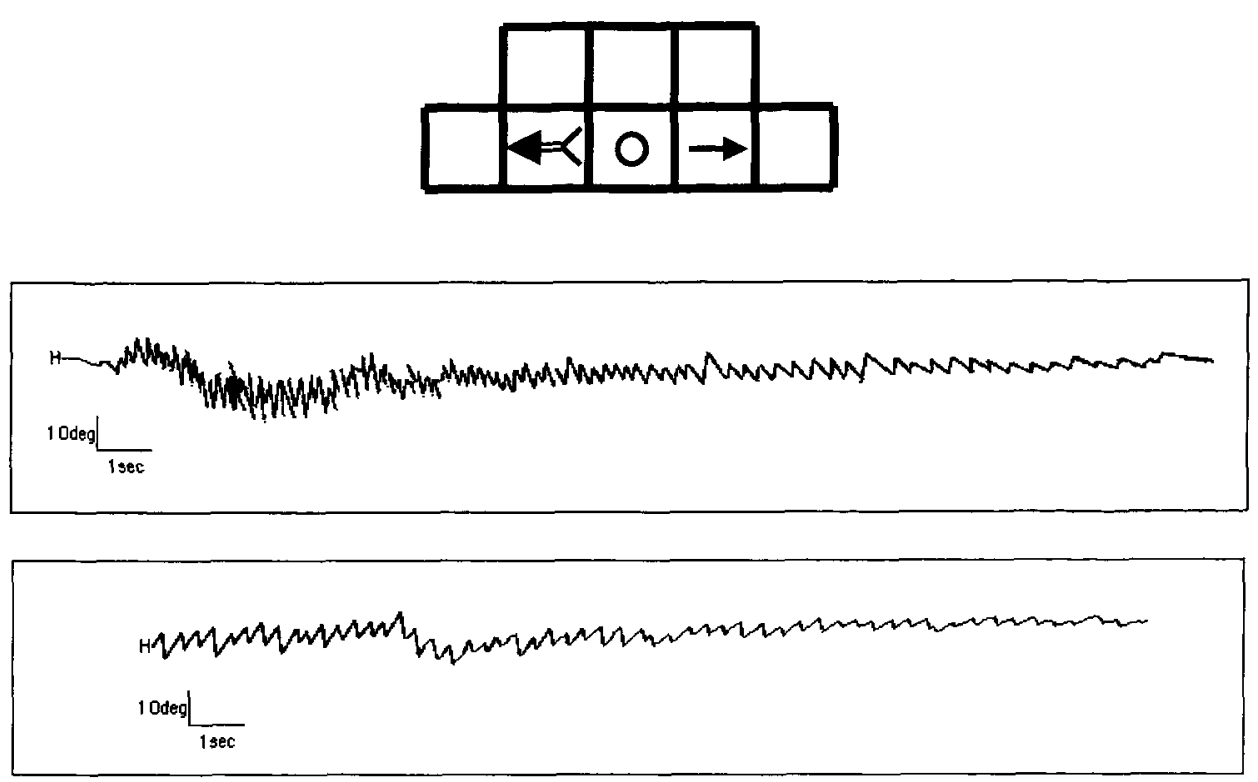

図 3 上段 : 頭振り後の仰臥位での眼振所見 中段：仰臥位右向きの眼掁解析図

下段：仰臥位左向きの眼振解析図
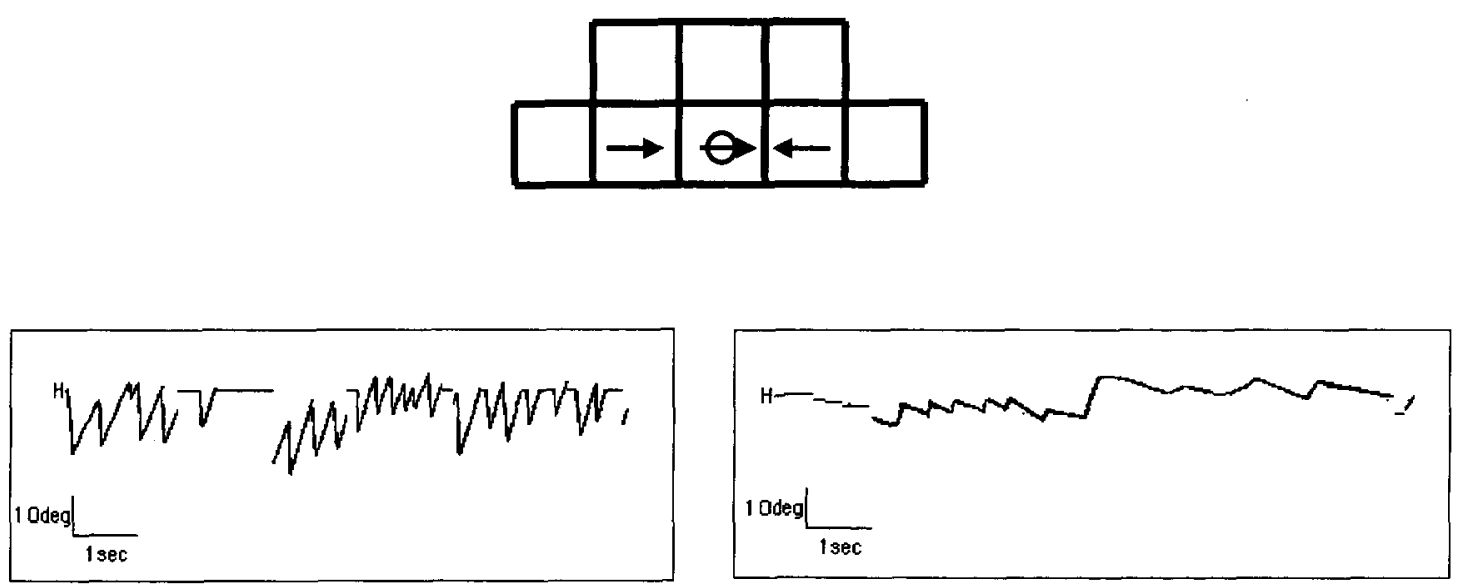

図4 上段 : 初診時の仰卧位での眼振所見

下段 : 左図は仰臥位右向きの眼振解析図 右図は仰臥位左向きの眼振解析図

標準純音聴力検查：両側高音障害 dip 型。 受診後経過 : 眼振所見及び他の諸検査から，左 外側半規管のクプラに debris が沈着した外側半 規管型（クプラ結石症）頭位めまい症と診断した。 そこで, 症例 1 と同様に, 1 日 3 回 30 秒程度の坐 位での頭振りを施行させたところ，数日後からめ
まい感は軽減し，7 日後再診時には眼振所見は， 仰臥位右下頭位では右向き水平性眼振, 仰卧位左 下頭位では左向き办平性眼振となる方向交代性下 向性眼振となった（図 5 )。この眼振所見の変化 から, 左側の外側半規管型頭位めまい症がクプラ 結石症から半規管結石症に移行した状態であると 

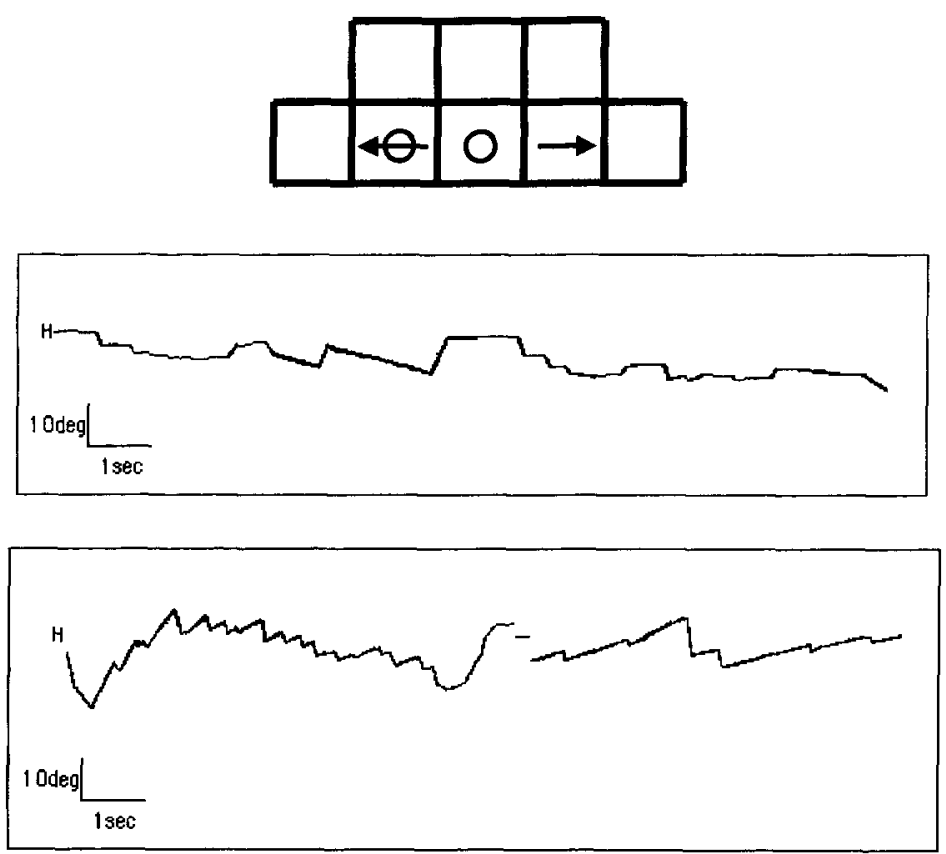

図 5 上段 : 頭振り後の仰臥位での眼振所見 中段 : 仰臥位右向きの眼振解析図 下段 : 仰臥位左向きの眼振解析図

診断し，同日左耳を患側として Lempert 変法施 行した結果, 直後より眼振は完全に消失した。外 来通院に和いて以後 1 力月間眼振の再然は認めな からた（その後他院へ転院となり，当科外来受診 なし)。

\section{考察}

良性発作性頭位めま(症 ${ }^{112)}$ 亿代表される末梢 性の頭位め实症は，日常臨床の場でよく経験 し，また予後良好な疾患として知られている15)。 外側半規管型頭位めまい症については，後半規管 型の良性発作性頭位めまい症での半規管結石症の 病態解明から，外側半規管に同様の病巣を有する

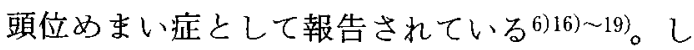
かしながら外側半規管型頭位めむい症は仰卧位で の眼振所見が水平成分主体であるため，中枢性の 疾患による眼振との鑑別が困難となり，臨床的に は診断苦慮し，その結果経過が遷延化すること も少なくない。加兄て外側半規管型頭位めまい症 に机いては，半規管結石症は Lempert 法6)等の 浮遊耳石置換法が有効である一方，クプラ結石症 では浮遊耳石置換法が無効であり，有効な治療法
に乏しかった。一般的に外側半規管型頭位めまい 症のクプラ結石症に対して Brandt-Daroff 法7) 等 の非特異的な理学療法が用いられているが，体全 体を側方に倒したり起こしたりするため，患者負 担が大きいといら問題があった。

そこで我々は, 外側半規管型頭位めまい症の》 プラ結石症に対して，坐位での頭振りを考案し た。理論的には図 2 左の如く坐位で頭部を30度程 度前屈位し（2)，体幹軸（11）を中心に頭振り をさせることにした。この姿勢では外側半規管が ほぼ水平性を保つためクプラの移動方向と重力の 方向が垂直となり，仰臥位の状態よりも重力の影 響を受けにくいものと推測した。患者本人の体動 も Brandt-Daroff 法と比較してかなり小さく，こ の点でも負担は小さいものと考它られた。 Brandt-Daroff 法では体動中の外側半規管にかか る遠心力が必ずしもクプラ結石に対して特異的で はないが，坐位での頭振りでは前者に比べ比較的 特異的に遠心力がかかるるのと考えられた。

今回提示した 2 症例の病態を推測すると, 症例 1に扣いては，初診時のクプラ結石症型のとさは 
図 6 の上段の如く，右下頭位では debris の影響 でクプラが反膨大部向きに偏位して左向きの水平 性眼振が出現し，左下頭位のときは， debrisの 影響でクプラが向膨大部向さに偏位し右向きの水 平性眼振が生じ，このため方向交代性上向性眼振 となったと考えた。坐位での頭振りの後, クプラ から debris が離れて半規管結石に移行した結果, 図6下段の如く，右下頭位のときは debris が重 力により移動して,内リンパ流動が向膨大部とな るため右向きの水平性眼振が生じ, 左下頭位の頭 位では， debrisによる内リンパ夜の流れが反膨 大部となるため左向きの水平性眼振が生じ，この ため方向交代性下向性眼振となったと考觉た。症 例 2 の病態は症例 1 と患側が異なるのみで同様な 病態であったと考えられた（図 7 )。クプラ結石 症では半規管結石症と比較し潜時が少なく持続し た眼振が出現し，半規管結石症では潜時を持った 疲労現象を伴う眼振が出現する。その理由として クプラ結石症では，クプラに付着した debrisに よる偏位が頭位を变換した直後より出現するこ と，更に頭位を変換している状態を維持している

\section{仰臥位右向き} （右側外例半規管を㰯側より見ている)
間偏位が維持されること等が考息られている1115)。 本症例の眼振所見も同様な特徵を呈していた（図 1, 図 4)。患耳決定については, 半規管結石症 では強い眼振が誘発される頭位で下の耳が患耳で あり，クプラ結石症ではその逆とされる15)。本症 例での患側決定に扎いても同様な理論的根拠で患 側を決定した。仰臥位で外側半規管のクプラは垂 直軸に一致せず，内側に少し傾いてクプラの先端 が外側を向いているといら理由から，頭位眼振の neutral positionにより患側を決定できるとの報 告19）むある。このことは本症例に颃いては, 症 例 1 の図 1 亿和いて仰臥位の正面で右向きの眼振 が出現していること, 症例 2 の図 4 において仰卧 位の正面で左向きの眼振が出現していることの理 由と考觉られた。

本症例で実際に坐位での頭振りを施行させたと ころ，患者自身のめまい症状による負担も小さく 比較的容易に施行させることが可能であった。経 過中 2 症例とも頭振りを施行させ，その後比較的 早期にクプラ結石症から半規管結石症へと移行さ せることが可能であった。しかしながら，自然経
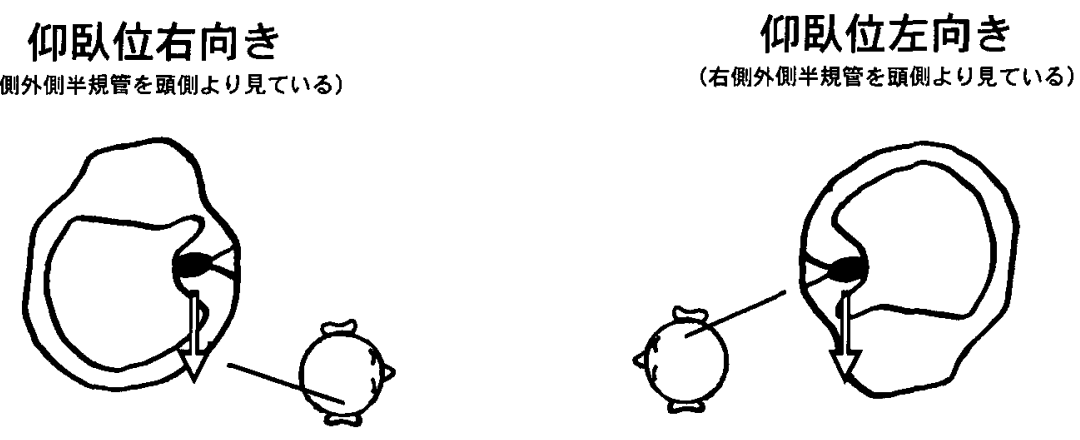

仰臥位右向き

（右側外例半規管を頭例より見ている)

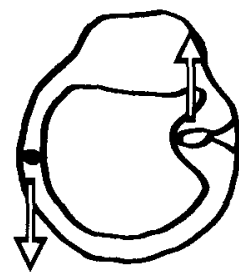

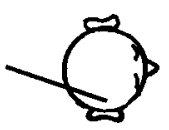

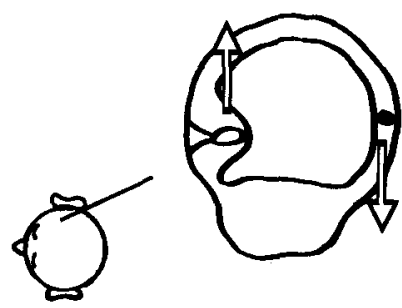

仰臥位左向き （右側外側半規管を頭側より見ている)

图 6 上段：初診時の仰臥位右向き・左向きでの推湘される病態 下段：頭振り後の仰卧位右向さ・左向きでの推測される病態 
仰臥位右向き

(在側外側半規管を皟側より見ている)

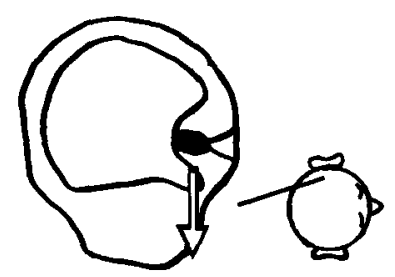

仰臥位右向き

（左側外側半規管を頭側より見ている）

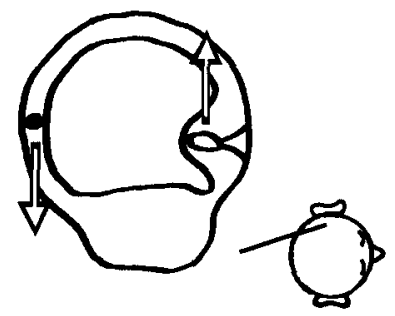

仰臥位左向き

(左側外㑡半规管を皟側より見ている)

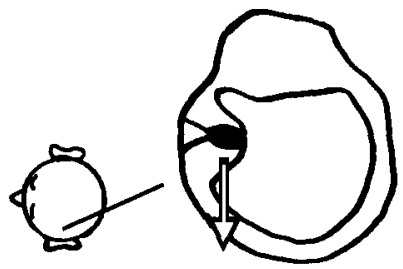

仰臥位左向き

（左側外側半規管を頭側より見ている）

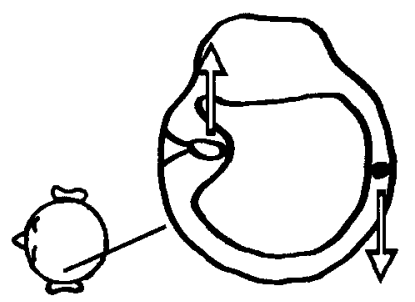

図 7 上段 : 初診時の仰臥位右向き・左向きでの推測される病態

下段: 頭振り後の仰臥位右向き・左向きでの推测される病態

過や日常診療での平衡機能検査によって移行した 可能性も否定できないため,この点については今 後, 痽病期問等の比較検討をする必要性があると 考光た。

外側半規管型（クプラ結石症）頭位めまい症に 扣いて最も重要な点は中枢性疾患の否定である が, その上で, 坐位での頭振りを施行させた結果 として眼振所見が方向交代性上向性から下向性へ と変化し, 浮遊耳石㯰換法により眼振が消失でさ れば, 診断がより確定的なものになると考えられ た。今回外側半規管 (クプラ結石症型) 頭位めま い症に対して, 坐位での頭振りを行い，比較的容 易かつ小さな患者負担で半規管結石症型へと移行 させることが可能であったと考えた。今後更に症 例を重㱛その有効性を検討していさたいと考兄 る。

\section{まとめ}

1) 外側半規管型 (クプラ結石症型) 頭位めま い症 2 症例を経験した。

2 ）坐位での頭振りは，小さな患者負担でクプ
ラ結石症を半規管結石症に移行することが可能で あった。また半規管結石症に移行後は, Lempert 変法が有効であった。

本論文の要旨は，第60回日本めまい平衡医学会 総会 (東京都)に执いてロ演した。

\section{文献}

1) Barany R: Diagnose von Krankheitserscheinungen im Bereiche des Otolithenapparates. Acta Otolaryngol 2: 434-437, 1921

2) Dix R, Hallpike CS: The pathology, sympyomatology and diagnosis of certain common disorders of the vestibular system. Ann Otol Rhinol Laryngol 61: 987-1016, 1952

3) Hall SF, Ruby RRF, McClure JA: The mechanics of benign paroxysmal vertigo. $J$ Otolaryngol 8: 151-158, 1979

4) Epley JM: The canalilith repositioning procedure: For treatment of benign paroxysmal vertigo. Otolaryngol Head Neck Surg 
107: 399-404, 1992

5 ) Schuknecht HF: Cupulolithiasis. Arch Otolaryngol 90: 765-778, 1969

6) Lempert T, Tiel-Wilick K: A positional maneuver for treatment of horizontal-canal benign positional vertigo. Laryngoscope 106: 476-478, 1996

7 ) Brandt T, Daroff RB: Physical therapy for benign paroxysmal positional vertigo. Arch Otolaryngol 106: 484-485, 1980

8 ）麻生 伸, 安村佐都紀, 浅井正嗣, 他 : 良性 発作性頭位脑量症 (BPPV) に対する Epley 法の効果. Equilibrium Res 54: 547-552, 1995

9）一條宏明, 阿部聡子, 石井賢治, 他：頭位眩 軍症に対する浮遊耳石置換法の効果. 耳鼻臨 休 89: 299-304, 1996

10）林賢，林 直樹，鈴木 筨，他：頭位眩 量症に対する頭位变換療法の有効性一後半規 管型について一。耳鼻臨床 91: 341-345, 1998

11）鈴木 衛, 林 直樹, 林 賢, 他: 外側半 規管型良性発作性頭位眩量症に対する頭位変 換療法の効果. 耳展 40: 535-538, 1997

12) 藤井 守, 井口郁雄, 綾田展明, 他 : 外側半 規管型 BPPV に対する耳石置換法.耳鼻臨
床 92: 15-20, 1999

13）井上裕章, 平野哲雄： horizontal canal BPPV 症例の検討. 耳鼻 45: 522-525, 1999

14）池田卓生, 綿貫浩一, 菅原一真, 他 : 赤外線 CCD カメラとパソコンを用いた簡易的眼球 運動画像解析法. Equilibrium Res 59: 298305,2000

15）武田憲昭：良性発作性頭位めまい症一臨床疫 学々病態生理一. 耳鼻臨床 94: 763-776, 2001

16) McClure JA: Horizontal canal BPV. J Otolaryngol 14: 30-35, 1985

17) Pagnini $P$, Nuti $D$, Vannucchi P: Benign paroxysmal vertigo of the horizontal canal. ORL 51: 161-170, 1989

18) Casani A, Giovanni V, Bruno F, et al: Positional vertigo and ageotropic bidirectional nystagmus. Laryngoscope 107: 807-813, 1997

19) Bisdorff AR, Debatisse D: Localising signs in positional vertigo due to lateral canal cupulolithiasis. Neurology 57: 1085-1088, 2001

$\left(\begin{array}{l}\text { 原稿到着 : 平成 } 14 \text { 年 } 3 \text { 月 } 11 \text { 日 } \\ \text { 別刷請求先 : 堀池 修 } \\ \text { 干755-8505 山口暻宇部市南小串1-1-1 } \\ \text { 山口大学医学部耳鼻咽喉科学教室 }\end{array}\right)$

